\title{
KEY VALUES OF BUSINESS-TO-BUSINESS RELATIONSHIP MARKETING
}

\begin{abstract}
The main subject of this paper is to introduce the most significant values of business-tobusiness relationship marketing. The attention is particularly paid to mutual value creation, longterm co-operation, loyalty and customer retention due to the most fundamental buyer-seller relationships based on trust. Moreover, the relationship marketing, business-to-business co-operation in the context of basic marketing relationships are described. The relationship marketing, regarding to Gummesson's definition, is seen in the context of relationships, networks and interaction. This approach underlines the meaning of relationship management, which aims at creation, development, and maintenance of network in which the company succeeds. Moreover, there is a strong need for interaction between buyers and sellers due to produce and sell the goods and services with impact on direct, personal communication. The relationship marketing is the value itself in the process of interaction between parties involved, as it provides the rule of equity between co-operating companies of more winning and less loosing situations.

This paper highlights the value of co-operation, however does not exclude competition. Cooperation and competition are treated inseparably in business. There is also a concern for activity and taking responsibility by parties involved described as well as the importance of relationship and service values instead of bureaucratic-legal values stressed. Customers need to be in focus, respected, treated individually as they are the purpose of value creation in the business-tobusiness relationship marketing.
\end{abstract}

Keywords: relationship marketing, values, co-operation, business-to-business

\section{INTRODUCTION}

"Marketing moves"2, quoting Harvard Business School modern representatives, from the traditional, transactional marketing mix concept to the contemporary relationship marketing one. The purpose of a business is to create and keep a customer ${ }^{3}$. No longer should customers be treated as segmented masses but as individuals, moreover, partners. According to Voss and $\mathrm{Voss}^{4}$, many viewpoints compare marketing relationships to a marriage marked by the ongoing mutual commitment and interest of both parties, while other viewpoints conceive that

\footnotetext{
${ }^{1}$ Małgorzata Wiśniewska, PhD, Poznan University of Technology, Faculty of Engineering Management, Chair of Management and Computing Systems, 11 Strzelecka Str., 60-965 Poznań, Poland, phone: +48 61 6653387, e-mail: malgorzata.wisniewska@put.poznan.pl

${ }^{2}$ D. C. Jain, S. Maesincee, Ph. Kotler, Marketing moves: A new Approach to Profits, Growth and Renewal, Harvard Business School Publishing Corp. 2002.

3 T. Levitt, After the sale is over, "Harvard Business Review" 1983.

${ }^{4}$ G.B. Voss, Z.G. Voss, Implementing a relationship marketing program: a case study and managerial implications, "The Journal of Services Marketing" 11/4 (1987).
} 
relationship marketing is an asymmetrical marketing process that requires an in-depth, personalized understanding of customer needs and characteristics.

Today's business success depends on mutual value creation, particularly based on trust, loyalty and long-term co-operation. Close co-operation with strategic customers (partners) leads to improved product quality, increases customer satisfaction, reduces costs, expands access to market information and new technologies, furthermore, creates a high threshold of competitiveness.

All theorists and practitioners argue that there is no single definition of relationship marketing, common to all markets and operating in their respective industries. Markets are very different, also subjected to ever-changing influences which shape different types of relationships. The multiplicity and the nature of the relationship would prevent its categorical definition. Regardless, for the purpose of this paper, the relationship marketing is understood as Gummesson ${ }^{5}$ put it: "marketing seen as relationships, networks and interaction", moreover, marketing seen as relationship management: "creating, developing, and maintaining a network in which the company thrives". Then as interactive which stands for: "bilateral and multilateral seller-buyer activities to produce and deliver goods and services, primarily in a person-toperson communication with less left to mass communication". Lastly, relationship marketing could be seen in the aspect of long-term, underling that: "relationships need time to be built and to be maintained".

Gummesson ${ }^{6}$ characterizes relationship marketing as "value for the parties involved, created through an interaction process between sellers, buyers, competitors and others. Cooperators are often co-producers who create value for each other in a joint effort". Values of the relationship marketing stand for "more win-win and less win-lose, for more equal parties. All parties carry a responsibility and can be active in a relationship, long-term relationships".

Relationship marketing is a combination of recognized marketing concepts such as marketing mix, the network approach to industrial marketing, services marketing, and internal marketing. "It is more than marketing management, it is rather marketing-oriented management an aspect of the total management of the firm - and not limited to a marketing or sales department. Moreover, relationship marketing is the marketing manifestation of the imaginary (virtual, network) organization - and vice versa"7.

It is worth to underline that relationship marketing offers some advantages to the company as "increases customer retention and duration, marketing productivity and thus profitability, and increases stability and security". Gummesson ${ }^{8}$ also distinguishes some advantages to the market economy saying that: "relationship marketing adds co-operation to competition and institutions. The symbiosis between these three forces contributes to a marketing equilibrium, a dynamic and optimal balance of the market economy seen from a marketing management

\footnotetext{
${ }^{5}$ E. Gummesson, The New Marketing - Developing Long-Term Relationships, "Long-Range Planning” $1987 / 4$, p. 11.

${ }^{6}$ E. Gummesson, Relationship Marketing as a Paradigm Shift: Some Conclusions from the 30Rs Approach, "Management Decision” 35/4 (1997), p. 267.

${ }^{7}$ Ibidem, p. 267-268.

${ }^{8}$ Ibidem.
} 
perspective". There are also many advantages to society and the citizen that should be quoted: "relationship marketing is marketing for the new economy - the service society, the information society, the postmodern society or the value society - which adds value through increased focus on customized production and one-to-one marketing; diminished focus on standardized mass manufacturing and anonymous mass marketing" (p. 268).

The relationship marketing meaning is evident in business-to-business as it is "largely conducted through networks of relationships. Therefore, relationship marketing can be applied to all kinds of companies and offerings". However, "the relationship range and the application is always specific to a given situation".

\section{CORE VALUES OF BUSINESS-TO-BUSINESS RELATIONSHIP MARKETING}

The core values of relationship marketing are found in its emphasis on co-operation and the creation of mutual value. It concerns viewing suppliers, customers and others as partners rather than opposite parties. In 1976 Baker already said that marketing should be defined as mutually satisfying exchange relationships. Relationship marketing should be beneficial for all those involved, and then all regards the relationship meaningful. If these conditions are fulfilled, the relationships have a chance to sustain. ${ }^{10}$

Co-operation is perceived as the fundamental value of relationship marketing, although both competition and co-operation are essential in a functioning market economy. Traditional marketing favors the benefits of competition whereas it sees co-operation as restraining the forces of the market. Relationship marketing approach treats co-operation as the reason for building an organization in order to create value together. However, quoting Gummesson ${ }^{11}$ : "In total relationship marketing you both collaborate and compete, inside as well as outside the organization", thus co-operation and competition are inseparable in the marketplace.

Relationship marketing highlights the value of existing customers, putting less stress on getting new ones. Together with CRM influence customer retention while simultaneously prevents customer defection. Retaining customers goes first, attracting customers second. ${ }^{12}$

Another fundamental value concerns activity and taking responsibility by parties involved. It is assumed that every co-operating company should be active and responsible for its actions. This approach is just opposite to the traditional point of view where the supplier is not a dynamic partner. In business-to-business marketing customers are the initiators of innovations in order to encourage suppliers to vary their products or services. ${ }^{13}$

Gummesson ${ }^{14}$ calls: "Relationship and service values instead of bureaucratic-legal values. Bureaucratic-legal values are characterized by: rigidity, legal jargon; application of dysfunctional laws and regulations; a focus on internal routines; more interest in rituals than in results;

\footnotetext{
${ }^{9}$ Ibidem, p. 268.

${ }^{10}$ Ibidem.

${ }^{11}$ E. Gummesson, Relationship Marketing in the New Economy, "Journal of Relationship Marketing” 2002/1, p. 52.

${ }^{12}$ E. Gummesson, Total Relationship Marketing, Butterworth-Heinemann, Oxford 1999.

${ }^{13}$ E. Gummesson, Total Relationship...

${ }^{14}$ Ibidem, p. 16.
} 
belief in the supplier as the expert and the customer as the ignorant; the customer being a cost and residual of the system; customers as masses and statistical averages; and the importance of winning over the customer in a dispute".

In the past, these values dominated the governments, public organizations and private companies as well. Today, relationship marketing requires different values based on relationships and services to the customer. According to these values, all customers are individuals and different in certain respects; the outcome is the only thing that matters; the customers are the source of revenue and should be in focus; and the supplier's task is to create value for customer. ${ }^{15}$ It is essential that marketers and top management understand and accept relationship values as natural vantage points. Otherwise, relationship marketing becomes a naive plan.

The ethical aspects of relationship marketing are also worth to discuss. Among frequently quoted values of relationship marketing one can find trust, honesty, goodwill, reliability, commitment and diligence. ${ }^{16}$

If the relationship is mutually beneficial, has a chance to exist. There cannot be any doubt in good intensions of partners. Communication understood as formal and informal exchange of important, credible and current information must be open, honest and frequent. ${ }^{17}$

Such regular communication influences both companies' interest and customers' welfare and guides to trust and trust leads to relationship commitment. Intensity of communication can determine customer view of so called special status and closeness which indicate proper relationships. The relationship marketers can develop their trust-worthiness by the opening lines of communication, guaranteeing the service, and a higher standard of conduct. According to Berry, success of communication during trust creation can have the influence on organizational structure, particularly in companies who deal with customers in the course of different representatives dedicated to every service contact. Sometimes companies need to reorganize its service systems in order to assign single representative to specific geographic area or customer segment.

"Delivering services through cross-functional teams also fosters service continuity and communications with customers. Customers are served by a team for most of their service requirements, giving a big company the opportunity to deliver a level of personalized service more characteristic of a small company". So, communication is the one mean to build the trust, while guaranteeing the service may be another one. It is especially important when company deals with customer's dissatisfaction. Guaranties the company gives to their clients "symbolize a company's commitment to fair play with customers and facilitate competitive differentiation; also, force the organization to improve service to avoid the cost and embarrassment of frequent payouts". The quality level of guarantees should never be poor; moreover, the companies should constantly improve their service quality. Companies looking for genuine relationships with their customers need to offer a higher standard of performance than just legality. "Relationship marketers must be prepared to subject every policy and strategy to

\footnotetext{
${ }^{15}$ Idem, Relationship Marketing in the New Economy..., p. 50-52.

${ }^{16}$ Idem, Relationship Marketing as a Paradigm Shift..., p. 269.

${ }^{17}$ J. Światowiec, Więzi partnerskie na rynku przedsiębiorstw, PWE, Warszawa 2006, p. 152.
} 
a fairness test. They must be willing to level the playing field, and ask not only if it is legal, but also if it is right". ${ }^{18}$

As demonstrated, the relationship building depends on the foundation of trust which is "a willingness to rely on an exchange partner in whom one has confidence". ${ }^{19}$ Moreover, parties involved in the relationship must understand and appreciate the act of giving, instead of just getting, therefore must adhere to comparable values. When parties trust each other the risk of failure decreases. Moreover, it should be noticed that "the degree and significance of trust vary extensively between cultures and nations". ${ }^{20}$

In the following part the general values of business-to-business relationships are presented as the synthesis from research within the B2B network approach; studies within sociology and psychology conducted since the 1970s.

Co-operation is perceived as a crucial value of relationships and can be connected with single deal as well as be constant. Gummesson ${ }^{21}$, quoting Wilkinson and Young ${ }^{22}$, says that the degree of co-operation could be combined with the degree of competition. Therefore, when talking about a situation with little competition and little co-operation between companies one can find it an excellent beginning of long-term mutual co-operation. On the other hand, a high degree of co-operation and a low degree of competition supports continuousness and peacefulness of a relationship. The relationships are able to prosper in a situation of both extensive co-operation and competition. However, if the competition determines and cooperation becomes less important, the relationship needs to be reconsidered.

"The long-term relationship is a pillar of RM"23, that is why it can become more useful for co-operating parties, when more time-consuming. When time passes by, the parties have an opportunity to better know each other, to become closer to each other, to work on the relationship in order to make it beneficial to all of them. Sometimes happens the relationships are unsatisfactory and should be broken.

The employees play the crucial role in relationships' longevity, "the longer employees stay with the company, the better they are able to serve their customers" 24 . Long-term employees better know the business and have more opportunities to develop bonds of trust and familiarity with customers. However, according to Reichheld, it is very important to decide on the appropriate employees who are to be kept in the company due to their usefulness in relationship marketing. He encourages companies to reconsider the practice of rotating managers through a

\footnotetext{
${ }^{18}$ L. Berry, Relationship Marketing of Services - Growing Interest, Emerging Perspectives, "Journal of the Academy of Marketing Science" 23/4 (1995), p. 243.

${ }^{19}$ C. Moorman, D. Rohit, G. Zaltman, Factors affecting trust in market research relationships, "Journal of Marketing" 57/21 (1993), p. 3.

${ }^{20}$ E. Gummesson, Total Relationship Marketing..., p. 23.

${ }^{21}$ Ibidem, p. 21-22.

22 I. Wilkinson, L. Young, On Co-operating: Firms, Relationships and Networks, "Journal of Business Research" 55/2 (2002).

${ }^{23}$ E. Gummesson, Total Relationship Marketing..., p. 22.

${ }^{24}$ F. Reichheld, Loyalty-Based Management, "Harvard Business Review” March-April 1993, p. 68.
} 
series of branch offices, because it negatively influences the long-term perspective needed in relationship marketing.

The success of every relationship depends on the engagement. "If the relationship is important, we are dependent on it, so we must commit ourselves to making it work" ${ }^{25}$ Reliance is extremely important in case of a crisis. In services marketing there are three levels of dependency and commitment proposed by Berry and Parasuraman in 1991, as Gummesson agreed. The first level occurs when customers are attracted by low prices above all. But if the competition behaves the same way by lowering the prices, the achievement is none. This level is commonly imitated. The second level appears when the relationship has been intensified. The price level becomes less important in favor of a closer one-to-one communication with the customer. When the parties reach the last level it means that the structural dimension takes place and companies have joined their resources. At the third level their commitment is very strong to invest in developing the relationship.

The relationships may be bothered by the concept of power. The symmetry of power can vary in time. Power in the relationships may be of two kinds: symmetrical or asymmetrical. The symmetrical means that each party has the same amount of power. If the relationship is asymmetrical, one party may feel uncomfortable or used. So the relationship exists if there is no opportunity for fair enough. Nonetheless, no one should be used excessively to maintain a relationship; therefore the parties should feel obliged to respect each other. ${ }^{26}$

In lasting relationships the parties need to adjust to each other. ${ }^{27}$ Such adaptation may become expensive, as concerns some investments, and lasts for a very long time, particularly in industrial markets.

Business long-term relationships also need an attraction factor between the parties to begin and remain. Some studies have shown that attraction between companies may require a combination of rational financial motives and psychological factors. Even in business, just like in the marriage, a partner should be worth a desire. In business-to-business some relationships become very personal, especially when partners see each other frequently and have some private connections. Closeness seems important as makes possible mental and emotional contact. $^{28}$

Companies call for informality as a part of formal contracts. If the parties trust each other the problems can be solved for example by the phone. Formal discussions may take place on other than business occasions, for example in the club. Nevertheless, partners should not forget about the formal aspects of their relationship. One of them is transparency. Parties should consider the extent of what they want to reveal to each other, for example, own costs or revenues. ${ }^{29}$

\footnotetext{
${ }^{25}$ E. Gummesson, Total Relationship Marketing..., p. 22.

${ }^{26}$ Ibidem, p. 23.

${ }^{27}$ Ibidem, p. 24.

${ }^{28}$ Ibidem, p. 25.

${ }^{29}$ Ibidem, p. 26
} 
After a period of time the majority of relationships turn into routine. Although it seems discouraging, routine procedures can be necessary for efficiency and cost effectiveness, Gummesson $^{30}$ claims. In B2B, routines are established for deliveries; both, the customer and the supplier are to obey regular procedures. There should be a compromise between routines and standard procedures for speed and low costs as well as feeling that the relationship lives and develops.

According to Gummesson ${ }^{31}$, the content of business relationships is usually seen as ordinary economic exchange. Marketing is the exchange in this sense. However, in relationship marketing the meaning of business relationship has changed - the relationship is seen as interaction and joint value creation. Its content is often knowledge and information.

The importance of each value described above is relative to a particular situation. Therefore, the power may be in some circumstances more significant than commitment and trust which are undeniably crucial. Certainly the ability to co-operate must always be the most important in the relationship.

Above values can contribute to the evaluation of a relationship, its development or liquidation, but alone cannot be sufficient enough for marketing decisions, planning and execution. ${ }^{32}$ Even if each of them highlights an interesting phenomenon, they must be put into context. "The basic values of relationship marketing should include the acceptance - in action, not only in rhetoric - of interactive relationships and a win-win situation; of both the buyer and the seller and other parties being drivers of a network of relationships; of long-term relationships being advantageous to the parties involved; and of the customer being a co-producer of value and a partner. Otherwise there will be no positive effect on relationship marketing". ${ }^{33}$

\section{CHARACTERISTIC OF BUSINESS-TO-BUSINESS RELATIONSHIPS}

The relationship marketing concept puts customers at the first place and has them in focus, opposite to the traditional marketing management approach. Frequently "mass marketing treats customers as statistics, decimals, and averages of grey masses, whether it is a large general mass or smaller mass segment". ${ }^{34}$ In addition, it is considered that the mass promotion and mass distribution are cost-effective, that is why most companies do not want to treat customers individually believing it is too expensive. On the contrary, relationship marketing concept underlines that company success arises from developing relationships with customers as individuals.

Gummesson $^{35}$ gives the example of Wind and Rangaswamy who extended relationship marketing approach to the concept of customerization which is a suggestion to every manager to start immediately interacting with customers and building relationships with them. "Rela-

\footnotetext{
${ }^{30}$ Ibidem.

${ }^{31}$ Ibidem.

${ }^{32}$ Ibidem.

${ }^{33}$ Idem, Relationship Marketing as a Paradigm Shift..., p. 267-268.

${ }^{34}$ E. Gummesson, Relationship Marketing in the New Economy..., p. 50-51.

${ }^{35}$ Ibidem, p. 51.
} 
tionship marketing requires managers to start with each individual and build from there, either keeping the customer as an individual, or making customers members of communities according to their wants and behavior. If a company looks at the market as an anonymous mass and then divides it, the customer becomes no more than a residual in a hierarchy".

Drucker in the 1950s said that "marketing is the whole business seen from the point of view of its final result, that is, from the customer's point of view." The essence of marketing concept is to understand customer needs and wants. If a company offers goods and services that satisfy needs and create value for the customer, customer satisfaction and the right customer perceived quality, the company has the greatest chance to success. This is marketingoriented and customer-centric approach, completely different from production orientation, according to which the customer is obliged to buy what is offered or not to buy at all. Therefore, it is advised to broaden marketing management into marketing-oriented management that is one of the basic relationship marketing principles. ${ }^{36}$

Companies which appreciated the marketing-oriented management and agreed that continuous improvement and innovation of relations with customers are the premises of their success understood that keeping customers is more important than acquiring them.

Some portrays relationships to be important under any circumstances. Reichheld and Sasser $^{37}$ underline increased profitable growth from long-term customers over less profitable short-term customers. The research conducted in variety of service industries proved that the profits increase steeply when a company successfully decreases its customer-defection rate. They found out, after analyzing over 100 companies, that the companies could improve profits from 25 percent to 85 percent by reducing customer defections by just 5 percent. It has been concluded that not only loyal customers generate more revenue for more years; the costs to maintain existing customers often are lower than the costs to get new ones. So, relationship marketing benefits not only the customer but the company as well. Others ${ }^{38}$ claim that only certain types of relationships are worth building, whereas some are not worth invested in, and should even be ended. This point arises from the view that long-term customers may not be necessarily more profitable than short-term customers, and that not all customers may be interested in developing relationships with companies. According to such approach, customers are seen as being in different levels of relationships. It means that they are differently sensitive to marketing activities due to the relationship level. Therefore, relationships at diverse levels should be treated separately as required. ${ }^{39}$

Swedish scholars ${ }^{40}$ observed that companies concentrate on the financial value of customers to estimate which ones are profitable enough to have relationship with, or on searching for a customers' tendency to engage in a relationship with the company. It appeared that "the

\footnotetext{
${ }^{36}$ E. Gummesson, Relationship Marketing as a Paradigm Shift...

${ }^{37}$ F. Reichheld., W. Sasser, Zero Defects: Quality Comes to Services, "Harvard Business Review” 1990/IX-X, p. 107.

${ }^{38}$ K. Storbacka, J.R. Lehtinen, Sztuka budowania trwałych związów z klientami, Customer Relationship Management, Oficyna Ekonomiczna, Kraków 2001.

${ }^{39}$ C. Grönroos, J. Gummerus, K. Hellēn, M. Sääksjärvi, Love at First Sight or Long-term Affair? Different Relationship Levels as Predictors of Customer Commitment, "Journal of Relationship Marketing" 6/1 (2007).

${ }^{40}$ C. Grönroos, J. Gummerus, K. Hellēn, M. Sääksjärvi, Love at First Sight..., p. 46-58.
} 
reasons for having relationships could be of multiple kinds". The researchers identified two levels of relationships. The first one, called a product-level relationship, indicates a relationship with a specific product, determined by the product attractiveness and involvement. At this level the relationship may evolve from a passive into an active one, which means that customers become more emotionally attached to the product; the product properties become less important. The second level of relationships, called a firm-level, means that the customer wants to engage into relationship with the entire company what leads customer to loyalty. Authors concluded that "the second relationship level may evolve from satisfaction with products which stem from product involvement".

The levels of relationship between the company and the customer were also in Payne's interest as illustrated in his marketing ladder of customer loyalty. The higher level of the ladder, the stronger the relationship. Payne notes that many companies prefer focusing on the lower level relationships (prospects and existing customers) which are often not served enough, than on the higher level relationships which show tendency to evolve from the clients into the partners. The reason may lie in the obstacles which companies encounter in shifting customers from the bottom to the top levels of the loyalty ladder. Companies may be successful only if they learn about their customers' needs and wants. However, it is not enough to follow the customers' expectations; therefore companies should most of all go beyond them in order to make a customer a supporter or an advocate.

According to Payne's ${ }^{41}$ view: "the best marketing is that done for you by your own customers, which is why the customer loyalty ladder and creation of advocates is so important". Referral markets, inferred from the relationship marketing six markets model, consist of existing customers or advocates, but also other business groups and organizations like, e.g., distributors, who can powerfully influence company's growth.

Companies should be aware the successful co-operation with referral markets needs time. Business should be done on the basis of the marketing plan, developed especially for the exact referral market and the effects as well as expenses need to be continuously monitored.

\subsection{The buyer-seller relationships}

The buyer-seller relationships constitute the foundations of marketing. Many scholars have contributed to industrial marketing by examining long lasting relationships between buyers and sellers. Some underlines that the core focus of industrial marketing should be on buyerseller relationships, instead of products or markets. Significant become the statement that suppliers and customers in industrial markets demand broad knowledge about themselves if they want to collaborate. However, it is rather not the information about the products they need, but the knowledge about the resources, organization and strategies. Therefore, it is necessary they create a kind of information platform for their companies to allow department specialists to communicate and exchange information.

\footnotetext{
${ }^{41}$ A. Payne, Relationship marketing: The six markets framework, working paper, Cranfield Graduate School of Management, 1993, p. 6.
} 
As IMP Group studies proved, there are numbers of personnel engaged in the relationships. Therefore, the confidence in the relationships is so important. The meaningful relationships are quite close, provided that the appropriate investments have been made. The indicator of the long term relationships is also "a match between the supplier's capability and customer's needs". This can involve parties to make some adjustments according to products, processes or organizational structures. Companies continuously learn how to adapt to each other in order to improve using their resources. Besides, they make a lot of investments in their relationships, e.g., in internal information channels or social relations. Companies stress that there are strong and specific connections between firms in industrial markets caused by quantitative as well as qualitative associations. Together they are able to "increase both transaction and production efficiency, gain access to much wider information and competence area, or gain some control over some important suppliers and customers, although they have to give up some of their autonomy in exchange". The findings also show that the relationships are the consequence of interactions between the firms. Due to these interactions, the suppliers and the customers may "establish, develop, and maintain relationships with each other". ${ }^{2}$

Referring to Turnbull and Valla ${ }^{43}$ "industrial markets are often characterized by stability and source loyalty, high costs of change of partner, power-dependence and, perhaps most importantly, by long-lasting supplier-customer relationships". In industrial marketing buyerseller relationships refer to satisfy mutual interests. Both parties engage in the long term relationship which is an "interaction process, varying in intensity at different stages of an individual relationship". This interaction approach sees relationships as "a self-regulation system, often involving such high levels of investment for the two counterparts that stability commonly characterizes industrial markets".

\section{CONCLUSIONS}

While deciding on implementing relationship marketing strategies, companies should remember about few fundamental values to make co-operation right. First of all, partners need to be trustworthy and loyal. The mutual trust is one of the basic values that influences the significance of the relationship. If there is no trust there is also no loyalty. It is worth to stress that the style of co-operation and the strength of the relationship usually depend on the past practices and experiences. The more satisfaction and effectiveness accomplished in the past, the more probability for partnership success for now and future.

Secondly, partners must achieve mutual understanding which is possible when they engage in the co-operation. The most important seems to be the role of management and their attitude towards building the partnership. But, the vitality of the relationship depends on the partners' approach too. Mutual engagement is a key element of any value creation.

\footnotetext{
${ }^{42}$ L. Hallen, J. Johanson, Networks of Relationship in International Industrial Marketing, JAI Press, Greenwich, CT, 1989.

${ }^{43}$ P. Turnbull, J. Valla, Strategies for International Industrial Marketing, Croom-Helm 1996, p. 2-4.
} 
To support the value creation in the relationship marketing companies can be suggested to obey some rules in accordance to co-operation. ${ }^{44}$ In brief, initially, it is necessary to build a team of well trained, qualified and trustful employees dedicated to the partner. Then, create a common policy to gain and share the knowledge due to developing joint practices. More, sustain smooth communication to predict, prevent and handle crisis situations. Finally, partners need to improve the system of co-operation all the time.

\section{REFERENCES}

[1] Berry L. Relationship Marketing of Services - Growing Interest, Emerging Perspectives, "Journal of the Academy of Marketing Science" 23/4 (1995).

[2] Berry L., Parasuraman A., Marketing Services: Competing Through Quality, The Free Press, New York 1991.

[3] Grönroos C., Gummerus J., Hellēn K., Sääksjärvi M., Love at First Sight or Long-term Affair? Different Relationship Levels as Predictors of Customer Commitment, "Journal of Relationship Marketing" 6/1 (2007).

[4] Gummesson E., The New Marketing - Developing Long-Term Relationships, "Long-Range Planning" $1987 / 4$.

[5] Gummesson E., Marketing-orientation Revisited: The Crucial Role of the Part-time Marketer, "European Journal of Marketing" 25/2 (1991).

[6] Gummesson E., Relationship Marketing as a Paradigm Shift: Some Conclusions from the 30Rs Approach, "Management Decision" 35/4 (1997).

[7] Gummesson E., Total Relationship Marketing, Butterworth-Heinemann, Oxford 1999.

[8] Gummesson E., Relationship Marketing in the New Economy, "Journal of Relationship Marketing" 2002/1.

[9] Hallen L., Johanson J., Networks of Relationship in International Industrial Marketing, JAI Press, Greenwich, CT, 1989.

[10] Jain D.C., Maesincee S., Kotler Ph., Marketing moves: A new Approach to Profits, Growth and Renewal, Harvard Business School Publishing Corp. 2002.

[11] Levitt T., After the sale is over, "Harvard Business Review" Sept-Oct 1983.

[12] Moorman C., Rohit D., Zaltman G., Factors affecting trust in market research relationships, "Journal of Marketing" 57/21 (1993).

[13] Payne A., Relationship marketing: The six markets framework, working paper, Cranfield Graduate School of Management 1993.

[14] Reichheld F., Loyalty-Based Management, "Harvard Business Review" March-April 1993.

[15] Reichheld F., Sasser W., Zero Defects: Quality Comes to Services, "Harvard Business Review" 1990/IX-X.

[16] Storbacka K., Lehtinen J.R., Sztuka budowania trwatych związków z klientami, Customer Relationship Management, Oficyna Ekonomiczna, Kraków 2001.

[17] Światowiec J., Więzi partnerskie na rynku przedsiębiorstw, PWE, Warszawa 2006.

[18] Turnbull P., Valla J., Strategies for International Industrial Marketing, Croom-Helm 1986.

[19] Voss G.B., Voss Z.G., Implementing a relationship marketing program: a case study and managerial implications, "The Journal of Services Marketing" 11/4 (1997).

\footnotetext{
${ }^{44}$ M. Wiśniewska, B2B Relationship Marketing Co-operation. [in:] Enterprise management. The customer perspective and internal processes management, ed. J. Kałkowska, E. Pawłowski, H. Włodarkiewicz-Klimek, Publishing House of Poznan University of Technology, Poznań 2013.
} 
[20] Wilkinson I., Young L., On Co-operating: Firms, Relationships and Networks, "Journal of Business Research" 55/2 (2002).

[21] Wiśniewska M., B2B Relationship Marketing Co-operation, [in:] Enterprise management. The customer perspective and internal processes management, ed. Kałkowska J., Pawłowski E., Włodarkiewicz-Klimek H., Publishing House of Poznan University of Technology, Poznań 2013.

\section{KLUCZOWE WARTOŚCI MARKETINGU PARTNERSKIEGO NA RYNKU PRZEDSIĘBIORSTW}

Tematem artykułu są wartości, zasadnicze z perspektywy marketingu partnerskiego, takie jak: współpraca, lojalność, zaufanie i utrzymanie klientów oraz współpraca na rynku business-tobusiness, w kontekście fundamentalnej relacji marketingowej pomiędzy sprzedającym a nabywcą. Marketing partnerski, w odniesieniu do definicji Gummesson'a, jest postrzegany w kontekście relacji, sieci i interakcji. Podejście to podkreśla znaczenie zarządzania relacjami, którego celem jest tworzenie, rozwijanie i utrzymywanie sieci powiązań, w której firma działa. Co więcej, istnieje silna potrzeba interakcji między kupującymi i sprzedającymi ze względu na wspieranie produkcji i sprzedaży towarów i usług, $\mathrm{z}$ naciskiem na bezpośrednią, a nie masową, komunikację. Marketing relacji jest wartością samą w sobie w procesie współpracy, ponieważ propaguje zasadę równości między partnerami, z naciskiem na „wygrać więcej, a nie wygrać mniej”. W artykule podkreślana jest wartość współpracy, jednak nie deprecjonuje ona znaczenia konkurencji, jako że współpraca i konkurencja są traktowane nierozdzielnie w biznesie. Marketing partnerski kładzie nacisk na aktywność współpracujących ze sobą przedsiębiorstw i nie uciekanie od odpowiedzialności. Klienci winni być szanowani, zawsze w centrum uwagi, traktowani indywidualnie, ponieważ to oni są sensem tworzenia wartości w marketingu relacji na rynku przedsiębiorstw. W związku z tym, partnerstwo zobowiązuje do przywiązywania większej wagi do budowania więzi opartej na współpracy w długim okresie czasu. Artykuł podkreśla także znaczenie wzajemnego zaufania i lojalności, które idąc w parze, wpływają na siłę i trwałość biznesowej relacji.

Słowa kluczowe: marketing partnerski, marketing relacyjny, wartości, współpraca przedsiębiorstw

\section{DOI: 10.7862/rz.2014.mmr.40}

Tekst złożono w redakcji: wrzesień 2014

Przyjęto do druku: październik 2014 